\title{
Engineered SNAP-MBD2b proteins for specific recognition of methylated DNA
}

\author{
ZOU DanDan, WANG XiaoLi, CHEN ZhiLan, ZHANG DaPeng \& WANG HaiLin* \\ State Key Laboratory of Environmental Chemistry and Ecotoxicology, Research Center for Eco-Environmental Sciences, \\ Chinese Academy of Sciences, Beijing 100085, China
}

Received August 13, 2013; accepted October 8, 2013; published online April 29, 2014

\begin{abstract}
Methyl-CpG-binding domain (MBD) proteins can specifically recognize and bind methylated CpG sites of DNA, thus repress gene transcription. In this study, we designed and expressed two recombinant proteins, MBD2b and SNAP-MBD2b, in E. coli. An optimized protocol was developed to purify the proteins using Ni-NTA affinity cartridge and cation exchange resin. The engineered proteins purified by this method exhibited more than $93 \%$ purity and high binding avidity. We found that both SNAP-MBD2b and MBD2b were prone to aggregate during dialysis. However, this could be prevented by the use of $0.3 \mathrm{~mol} / \mathrm{L}$ $\mathrm{NaCl}$. The fusion of SNAP-tag with MBD2b significantly enhanced the expression of MBD2b protein in $E$. coli and reduced the adsorption of MBD2b on solid interfaces involved in protein purification and immobilization. The engineered proteins can be used for the study of interaction with methylated DNA and the assays for DNA methylation.
\end{abstract}

methylated DNA, MBD2b, SNAP-MBD2b, SNAP-tag, histidine-tagged affinity chromatography (AC), cation exchange chromatography (CXC)

\section{Introduction}

DNA methylation is one of the most important epigenetic modifications in mammalian cells. It is involved in many cellular processes, such as transcriptional repression, embryonic development regulation, genomic imprinting, and $\mathrm{X}$-chromosome inactivation [1-3]. Aberrant methylation patterns, e.g., hypermethylation and hypomethylation, have been associated with aging, cancer, and other diseases [3, 4].

The methylated DNA signal is read out by the methylCpG-binding domain (MBD) proteins $[5,6]$. These proteins can recognize and bind methylated $\mathrm{CpG}$ sites to mediate transcriptional repression via recruitment of co-repressors such as histone deacetylases (HDAC), leading to chromatin condensation $[7,8]$. Consequently, they are thought to function as a protein-protein interface linker between DNA methylation and chromosome silence [7, 8]. Mutations in

*Corresponding author (email: hlwang@ @rcees.ac.cn) the MBD proteins can contribute to human diseases, such as Rett syndrome, a severe X-linked mental retardation that afflicts about one in 10000 girls [2]. Among all the MBD family members (MBD1, MBD2, MBD3, MBD4 and MeCP2), MBD2b protein, a small fraction of the total MBD2 proteins lacking $140 \mathrm{~N}$-terminal aa [5, 6], has the highest affinity for methylated DNA and displays the greatest capacity to differentiate between methylated and unmethylated DNA [9]. Based on the binding property of MBD, a series of analytical methods for detection of DNA methylation were established, such as methylated-CpG island recovery assay (MIRA) [10], MBD-isolated genome sequencing (MiGS) [11], and MBD column chromatography [12-15].

SNAP is a unique labeling tag for protein research, allowing specific and covalent attachment of virtually any molecule to a protein of interest $[16,17]$. It is an engineered variant based on human repair protein $\mathrm{O}_{6}$-alkylguanineDNA-alkyltransferase (hAGT) that covalently reacts with 
$\mathrm{O}_{6}$-benzyl guanine (BG) derivatives [16, 17]. SNAP-tag technique has been described not only for the study of the interactions between proteins, immobilization on solid surface, and pull-down assays, but also for the subcellular localizing such as the nucleus, endoplasmic reticulum [17-21].

In this report, we designed and expressed two recombinant proteins MBD2b and SNAP-MBD2b in E. coli. A simple and efficient two-step purification protocol was developed to purify these two proteins. This method uses histidine-tagged affinity chromatography (AC) and cation exchange chromatography (CXC). The advantages of AC, such as high binding capacity and high recovery yield, have made it a standard technique for the purification of recombinant proteins with unknown characteristics [22, 23]. However, one drawback of using Ni-NTA resin for purification of histidine-tagged proteins is the co-purification of contaminating histidine-rich $E$. coli proteins [24, 25], making the second polishing purification necessary. Ion exchange chromatography is also one of the most widely used separation techniques providing high capacity and good resolution [26, 27]. Since MBD protein is a basic protein, it has a net positive charge below its isoelectric point (pI). Theoretically, it can bind to a cation exchange resin. Our experiments demonstrated that MBD2b protein isolated by our method could achieve more than $93 \%$ purity. We further extended the method to the SNAP-MBD2b purification. Compared with MBD2b, fusion of SNAP-tag not only significantly enhanced expression of MBD2b protein, but also reduced the adsorption of $\mathrm{MBD} 2 \mathrm{~b}$ on the cartridge or column.

\section{Experimental}

\subsection{Strains, plasmids and oligonucleotides}

The bacterial strains and plasmids used in this study are listed in Table 1. E. coli DH5 $\alpha$ (Biomed, Beijing, China) was used as a host cell for DNA manipulation. E. coli Rosetta (DE3) (Biomed, Beijing, China), which was designed to enhance expression of eukaryotic proteins by supplying rare tRNA, was used for producing the recombinant proteins. The pCMV-SPORT6 vector (Funeng, China) and pSNAP-tag® (T7) vector (NEB, Beijing, China) were used as the PCR template for MBD2b gene and SNAP gene, respectively. The pET-52b vector (Novagen, Darstadt, Germany) was used to express the recombinant proteins. PCR primers (Table 2) used for cloning were synthesized and purified by Integrated DNA Technologies (Sangon, Beijing, China).

\subsection{Construction and transformation of expression vector}

Molecular constructions of two proteins were made with
Table 1 Bacterial strais and plasmids

\begin{tabular}{ll}
\hline \multicolumn{1}{c}{ Strains/plasmids } & \multicolumn{1}{c}{ Description/usage } \\
\hline DH5 $\alpha$ & $\begin{array}{l}\text { Colony strain } \\
\text { Expression strain, can enhance the expres- } \\
\text { sion of eukaryotic proteins in } E \text {. coli }\end{array}$ \\
Rosetta (DE3) & PCR template for MBD2b gene \\
pCMV-SPORT6 & PCR template for SNAP gene \\
pSNAP-tag® (T7) & C-terminal (Histidine) $)_{10}$-tag vector, Amp ${ }^{\mathrm{r}}$ \\
pET-52b & The pET-52b inserted the 808bp of MBD2b \\
pET-52b + MBD2b & gene \\
pET-52b + SNAP + & The pET-52b inserted the 546bp of SNAP \\
MBD2b & gene and 808bp of MBD2b gene \\
\hline
\end{tabular}

Table 2 Primers used to construct the recombinant expression plasmids

\begin{tabular}{cl}
\hline \multicolumn{1}{c}{ Primer } & \multicolumn{1}{c}{ Sequence $^{\text {a) }}$} \\
\hline MBD2b-F1 & $\begin{array}{l}\text { 5'GCGGATCCGATGGATTGCCCGGCCCTC3' } \\
\text { (BamHI) }\end{array}$ \\
MBD2b-R1 $\begin{array}{l}\text { 5'ATTAAGAGCTCGGCTTCATCTCCACTGTCCA3' } \\
\text { (SacI) }\end{array}$ & $\begin{array}{l}\text { 5'GC GGATCCTATGGACAAAGATTGCGAAATG } \\
\text { AA3' (BamHI) }\end{array}$ \\
SNAP-F & $\begin{array}{l}\text { 5'GATATGACATATGACCTGCAGGTCCCAGACC } \\
\text { CG3' (NdeI) }\end{array}$ \\
MBD2b-F2 & $\begin{array}{l}\text { 5'GATATGACATATGATGGATTGCCCGGCCCTC3' } \\
\text { (NdeI) } \\
\text { 5'ATTAAGAGCTCGGCTTCATCTCCACTGTCCA3' } \\
\text { MBD2b-RacI) }\end{array}$ \\
\hline
\end{tabular}

a) Underline, the restricted enzyme site.

pET-52b vector that has (histidine) $)_{10}$ affinity tags in its C-terminal. The coding sequences of SNAP and MBD2b gene were amplified by PCR method using the corresponding primer. For $\mathrm{pET}-52 \mathrm{~b}+\mathrm{MBD} 2 \mathrm{~b}$ construct, the primers MBD2b-F1 and MBD2b-R1 (Table 2) containing BamHI and SacI sites (underlined correspondingly) were used to amplify human MBD2b gene from pCMV-SPORT6 vector by PCR (Table 1). For pET-52b + SNAP + MBD2b construct, the SNAP and MBD2b fragments were amplified by the primers SNAP-F and SNAP-R containing BamHI and NdeI sites, MBD2b-F2 and MBD2b-R2 containing NdeI and SacI sites, respectively (Table 2). The pSNAP-tag® (T7) and pCMV-SPORT6 vectors (Table 1) were used as templates. The amplified fragments were then subcloned into pET-52b at BamHI and SacI sites. The constructed recombinant vectors are shown in Scheme 1. The resultant plasmids were transformed directly into the strain DH5 $\alpha$. Transformants were selected on LB plates containing 100 $\mu \mathrm{g} / \mathrm{mL}$ ampicillin. Recombinant plasmids were extracted and analyzed by PCR method and sequenced by Sangon, then transformed into competent Rosetta (DE3) strain for protein expression.

\subsection{Protein expression and sample preparation}

The recombinant E. coli cells were screened for protein expression. The positive ones were cultured in LB media ( $1 \%$ bacto tryptone, $0.5 \% \mathrm{NaCl}, 1 \%$ yeast extract) supplemented 

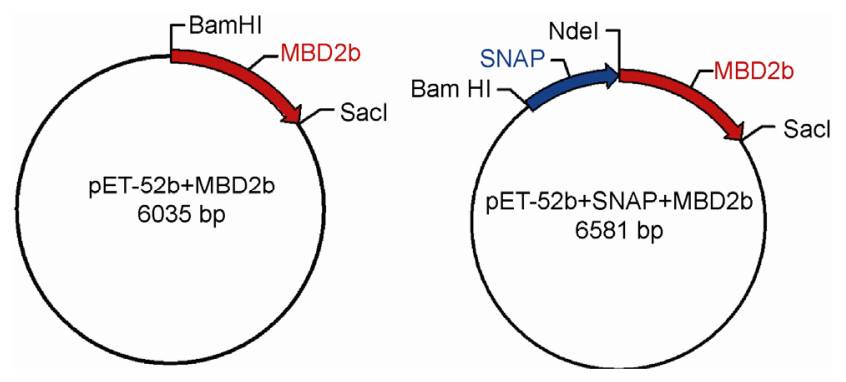

Scheme 1 The constructed pET-52b + MBD2b and pET-52b + SNAP + $\mathrm{MBD} 2 \mathrm{~b}$ recombinant vector.

with $100 \mu \mathrm{g} / \mathrm{mL}$ ampicillin. After overnight incubation, culture of the cell was used as starter to inoculate $3 \mathrm{~L}$ of fresh $\mathrm{LB}$ media. When the $\mathrm{OD}_{600}$ reached $0.8-1.0$, IPTG was added to reach a final concentration of $1 \mathrm{mmol} / \mathrm{L}$. Incubation was continued for another $2 \mathrm{~h}$ at $37^{\circ} \mathrm{C}$. The cells were harvested by centrifugation at $8000 \mathrm{rpm}$ for $20 \mathrm{~min}$ at $4{ }^{\circ} \mathrm{C}$. The cell pellets were lysed using $60 \mathrm{~mL}$ Bugbuster Protein Extraction Reagent with Benzonase Nuclease (Merck, Darmstadt, Germany), $1 \mathrm{mmol} / \mathrm{L}$ DTT, $1 \mathrm{mmol} / \mathrm{L}$ PMSF, $0.1 \%$ Triton $\mathrm{X}-100$, and $10 \%(v / v)$ glycerol. The mixture was incubated on ice for $20 \mathrm{~min}$, then centrifugated at $8000 \mathrm{rpm}$ for $20 \mathrm{~min}$ at $4{ }^{\circ} \mathrm{C}$. The supernatant was passed through a $0.22 \mu \mathrm{m}$ filter before the following purification steps.

\subsection{Histidine-tagged affinity chromatography (AC)}

Purification experiments were performed at $4{ }^{\circ} \mathrm{C}$ using AKTA purifier UPC10 system (GE Healthcare, Uppsala, Sweden). All buffers were filtrated through $0.22 \mu \mathrm{m}$ filter before use (Table 3). The prepacked HisTrap HP $5 \mathrm{~mL}$ column (GE Healthcare, Uppsala, Sweden) was used. Prior to purification, the column was pre-equilibrated with 5-10 column volumes $(\mathrm{CV})$ of $2 \% \mathrm{~B}$ to prevent unwanted host cell proteins from binding. The $60 \mathrm{~mL}$ of solubilized sample was applied onto the column at a flow rate of $1 \mathrm{~mL} / \mathrm{min}$ and the flowthrough (FT) was collected. After sample loading, the column was washed first with $15-20 \mathrm{CV}$ of $2 \% \mathrm{~B}$, then with $8 \% \mathrm{~B}$ at a flow rate of $2-4 \mathrm{~mL} / \mathrm{min}$. Finally, the bound proteins were eluted with $5-10 \mathrm{CV}$ of $25 \% \mathrm{~B}(250 \mathrm{mmol} / \mathrm{L}$ imidazole) at a flow rate of $1 \mathrm{~mL} / \mathrm{min}$. The eluates were collected.

Table 3 List of buffer used

\begin{tabular}{|c|c|}
\hline Technique & Buffer composition \\
\hline $\mathrm{AC}$ & $\begin{array}{l}\text { Port A: } 50 \mathrm{mmol} / \mathrm{L} \mathrm{NaH} \mathrm{PO}_{4}, 300 \mathrm{mmol} / \mathrm{L} \mathrm{NaCl}, 10 \% \\
(v / v) \text { glycerol, } 1 \mathrm{mmol} / \mathrm{L} \mathrm{DTT}_{1} 1 \mathrm{mmol} / \mathrm{L} \mathrm{PMSF}, \mathrm{pH} 8.0 \\
\text { Port B: } 50 \mathrm{mmol} / \mathrm{L} \mathrm{NaH} \mathrm{PO}_{4}, 300 \mathrm{mmol} / \mathrm{L} \mathrm{NaCl}, 10 \% \\
(v / v) \text { glycerol, } 1 \mathrm{mmol} / \mathrm{L} \mathrm{DTT}, 1 \mathrm{mmol} / \mathrm{L} \mathrm{PMSF}, 1 \mathrm{~mol} / \mathrm{L} \\
\text { imidazole, pH } 8.0\end{array}$ \\
\hline $\mathrm{CXC}$ & $\begin{array}{l}\text { Port A: } 50 \mathrm{mmol} / \mathrm{L} \mathrm{NaH}_{2} \mathrm{PO}_{4}, 100 \mathrm{mmol} / \mathrm{L} \mathrm{NaCl}, 10 \% \\
(v / v) \text { glycerol, } 1 \mathrm{mmol} / \mathrm{L} \mathrm{DTT}_{1} \mathrm{mmol} / \mathrm{L} \mathrm{PMSF}, \mathrm{pH} 7.4 \\
\text { Port B: } 50 \mathrm{mmol} / \mathrm{L} \mathrm{NaH} \mathrm{PO}_{4}, 1 \mathrm{~mol} / \mathrm{L} \mathrm{NaCl}, 10 \%(v / v) \\
\text { glycerol, } 1 \mathrm{mmol} / \mathrm{L} \text { DTT, } 1 \mathrm{mmol} / \mathrm{L} \mathrm{PMSF}, \mathrm{pH} 7.4\end{array}$ \\
\hline
\end{tabular}

\subsection{Cation exchange chromatography (CXC)}

The eluted proteins were polished by CXC. The pre-packed Hitrap SP FF 5 mL column (GE Healthcare, Uppsala, Sweden) was used. For MBD2b protein, the column was washed with $5 \% \mathrm{~B}(150 \mathrm{mmol} / \mathrm{L} \mathrm{NaCl})$, then with $11 \% \mathrm{~B}(200$ $\mathrm{mmol} / \mathrm{L} \mathrm{NaCl})$. For SNAP-MBD2b, the column was washed with $5 \% \mathrm{~B}(150 \mathrm{mmol} / \mathrm{L} \mathrm{NaCl})$ only. Eluted proteins were diluted three folds with CXC Port A buffer (Table 3) to decrease the $\mathrm{NaCl}$ concentration to $150 \mathrm{mmol} / \mathrm{L}$, then loaded directly onto column equilibrated with 5-10 CV of $5 \% \mathrm{~B}$ (containing about $150 \mathrm{mmol} / \mathrm{L} \mathrm{NaCl}$ ) at a flow rate of $0.5 \mathrm{~mL} / \mathrm{min}$. The FT was collected. Finally, the target protein was eluted using $23 \% \mathrm{~B}(300 \mathrm{mmol} / \mathrm{L} \mathrm{NaCl})$ at a flow rate of $1 \mathrm{~mL} / \mathrm{min}$. The two proteins were dialyzed against buffer $(20 \mathrm{mmol} / \mathrm{L}$ Tris-HCl, $\mathrm{pH} 7.5,1 \mathrm{mmol} / \mathrm{L}$ DTT, $1 \mathrm{mmol} / \mathrm{L}$ PMSF, $0.1 \%$ Triton X-100 and $10 \%$ glycerol) with a molecular cut-off of $14 \mathrm{~K}$. The final concentration of protein was measured via the Bradford assay.

\subsection{SDS-PAGE analysis and labeling of SNAP-tag}

SDS-PAGE electrophoresis was carried out using discontinuous gel with a $4 \%$ stacking gel and a $10 \%$ resolving gel of acrylamide. Samples were heated to $95{ }^{\circ} \mathrm{C}$ for $5 \mathrm{~min}$ before electrophoresis. After electrophoresis, separated proteins were stained with Coomassie Brilliant Blue R250. The bands were compared with pertained marker standards. The size of the purified protein was estimated using DNAman software (Table 4).

The snap activity was measured through direct labeling of SNAP-MBD2b protein with SNAP-surface alexa flour 488 substrate (NEB, Beijing, China). The mixture was incubated overnight at $4{ }^{\circ} \mathrm{C}$. MBD2b protein was used as the negative control. The sample was subjected to SDS-PAGE analysis and the gel was scanned with UV-transilluminator, then stained with Coomassie Brilliant Blue R250.

\section{Results and discussion}

\subsection{Histidine-tagged affinity chromatography}

Expression of MBD2b and SNAP-MBD2b proteins were induced by $1 \mathrm{mmol} / \mathrm{L}$ IPTG in Rosetta (DE3) strain, which was designed to enhance the expression of eukaryotic proteins in E. coli (experimental section). The good solubility of the two proteins allowed purification under gentle and

Table 4 Properties of MBD2b and SNAP-MBD2 $b^{\text {a) }}$

\begin{tabular}{ccc}
\hline Protein & Molecular mass $(\mathrm{kDa})$ & Isoelectric point $(\mathrm{pI})$ \\
\hline MBD2b & 34 & 9.32 \\
SNAP-MBD2b & 55 & 7.79 \\
\hline
\end{tabular}

a) The data was predicted by DNAman software. 


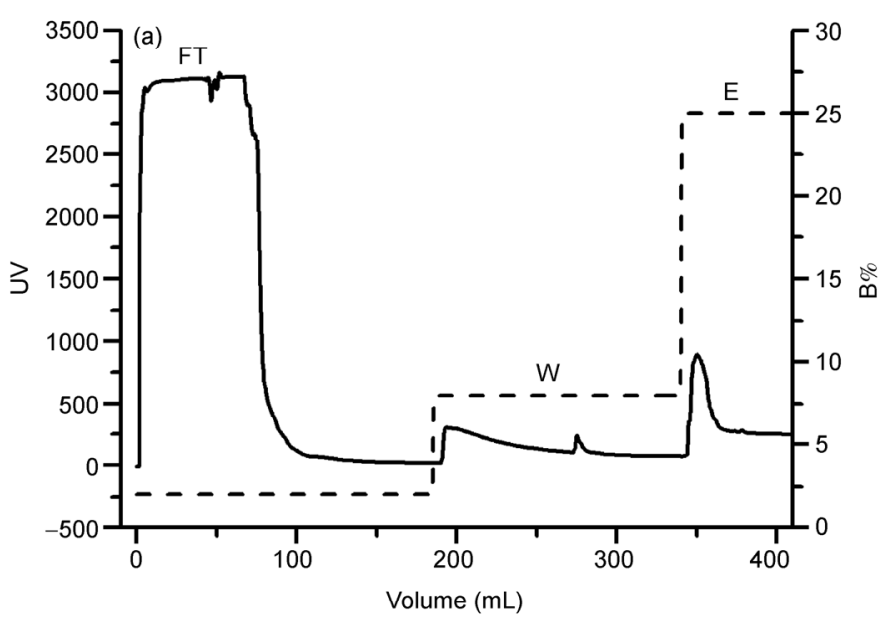

(b) $\underset{(\mathrm{kDa})}{\mathrm{Mr}} \mathrm{M} \quad \mathrm{L} \quad \mathrm{FT} \quad \mathrm{E} 1 \quad \mathrm{E} 2 \quad \mathrm{E} 3 \quad \mathrm{E} 4 \quad \mathrm{E} 5$
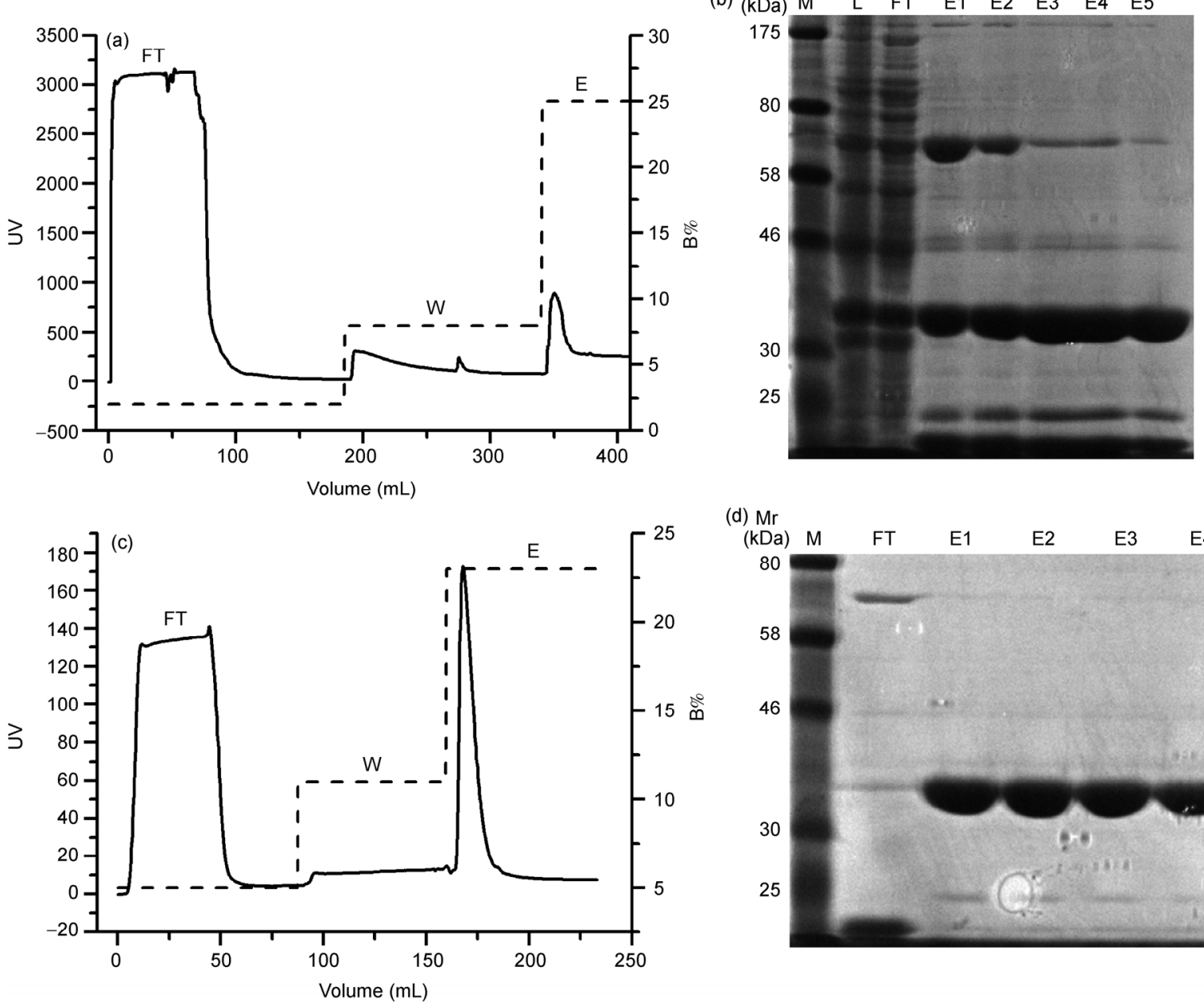

(d) $\mathrm{Mr}$
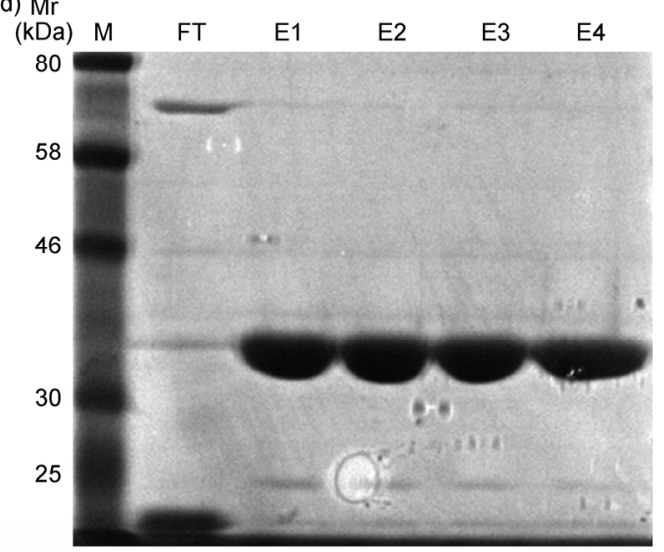

Figure 1 Purification of MBD2b protein using the two-step strategy. (a) The overview of AC process. The solid line represents chromatography profile, the dash line represents the percent of buffer B. UV: absorbance at $280 \mathrm{~nm}$; B\%: percent of buffer B; W: wash fraction; E: eluted fraction; (b) SDS-PAGE analysis of AC fractions. M: pertained protein marker; L: lysate; FT: flowthrough; (c) CXC process; (d) analysis of CXC fractions.

native conditions. Instead of sonication, we used Bugbuster (experimental section) to gently disrupt the cell wall of $E$. coli and release the two soluble proteins to retain their biological activity. Benzonase was used to decrease the viscosity of the samples due to the release of nucleic acids.

Since the recombinant proteins had a histidine-tag at their C-terminal, AC was chosen as the first capture step. Each crude protein extract was loaded onto the HisTrap HP $5 \mathrm{~mL}$ column. Fractions of FT and elution (E) were collected and analyzed by SDS-PAGE, using standard markers to estimate the molecular masses. Similar profiles were obtained for the Ni-NTA (Ni-nitrilotriacetic acid) affinity resins with the two recombinant proteins (Figure 1(a) and Figure 2(a)). While target proteins could be efficiently retained on the column (Figure 1(a,b) and Figure 2(a, b)), most of the impurities were removed in the FT fraction. After two step washing using $2 \% \mathrm{~B}$ (Table 3 ) and $8 \% \mathrm{~B}$, the bound proteins were eluted under $25 \% \mathrm{~B}$ in one peak. SDS-PAGE analysis showed that the eluted fractions contained one major band (34 kDa, MBD2b; $55 \mathrm{kDa}$, SNAP-
MBD2b, Table 4) with a few impurities (Figure 1(b) and Figure 2(b)). The pooled fractions were collected for CXC.

\subsection{Cation exchange chromatography}

We chose the neutral $\mathrm{pH} 7.4$ because MBD2b proteins have a net positive charge below its isoelectric point (pI) (Table 4 ), therefore can interact with a cation exchange resin. The $\mathrm{NaCl}$ concentration in the binding buffer is the key factor that influences the efficiency of CXC. Scouting runs revealed that binding buffer with $150 \mathrm{mmol} / \mathrm{L} \mathrm{NaCl}$ was optimally producing eluates with high purity without significant loss of the target protein in the FT fraction (data not shown). The eluted proteins from Ni-NTA purified sample were diluted three folds with the CXC Port A buffer (Table 3 ) to reduce the salt concentration to $150 \mathrm{mmol} / \mathrm{L}$. The concentration with $300 \mathrm{mmol} / \mathrm{L} \mathrm{NaCl}$ was chosen as elution buffer.

As shown in Figure 1(c), the impurities and target protein 

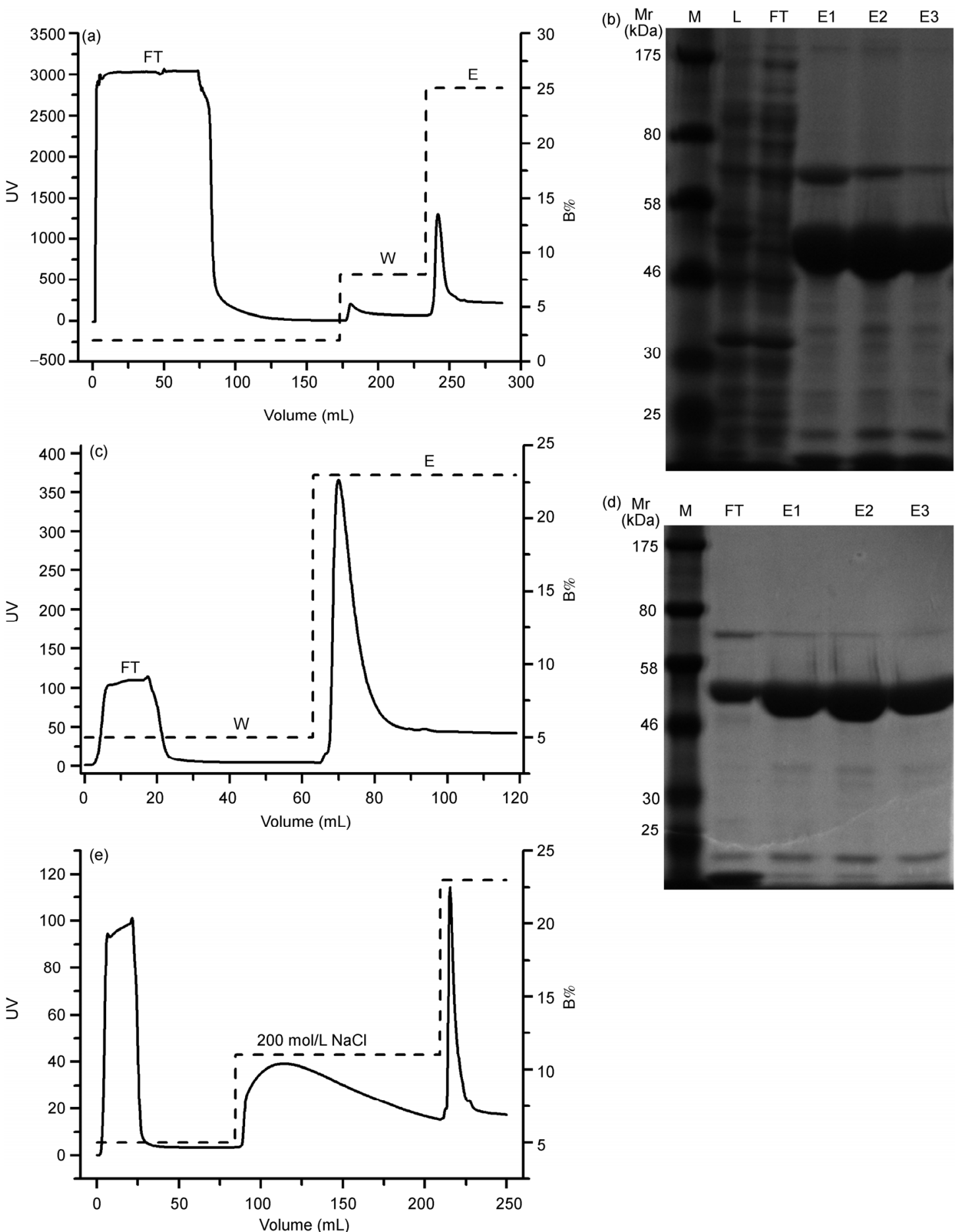

Figure 2 Purification of SNAP-MBD2b protein. (a) Overview of AC process; (b) SDS-PAGE analysis of AC fractions; (c) CXC process; (d) analysis of CXC fractions; (e) SNAP-MBD2b protein was washed with 5\% B (150 mmol/L NaCl), $11 \%$ B (200 mmol/L NaCl), and 23\% B (300 mmol/L NaCl).

were well resolved. The remaining contaminants were removed in the FT fraction. Almost no target protein was detected in the FT (Figure 1(c, d)), indicating efficient entrapment with no breakdown of target protein. This result suggests that low concentration of imidazole (about 60 $\mathrm{mmol} / \mathrm{L}$ ) didn't affect this binding process (Figure 1(d)). The bound proteins were eluted in one peak by increasing
$\mathrm{NaCl}$ concentration to $300 \mathrm{mmol} / \mathrm{L}$ (Figure 1(c)). SDS-PAGE analysis showed a single band with $94 \%$ purity (Figure $1(d)$ ). Since imidazole also absorbs UV at $280 \mathrm{~nm}$, the relatively high UV $280 \mathrm{~nm}$ signal in the FT fraction included both unbound protein and imidazole absorbance (Figure 1(c)). For SNAP-MBD2b protein, the purity level was about 93\% and no significant degradation fragments were observed 
(Figure 2(c,d)). These results show that high level of purity of the two proteins can be achieved through this two-step strategy.

One problem encountered during dialysis was that the $\mathrm{NaCl}$ level had to be maintained at $300 \mathrm{mmol} / \mathrm{L}$, otherwise proteins were prone to aggregate and precipitate. This might be attributed to their naturally high sensitivity to changes in $\mathrm{NaCl}$ concentration. They need high salt concentration to stabilize their conformation.

\subsection{Comparisons of purification between MBD2b and SNAP-MBD2b proteins}

Compared with MBD2b, the amount of SNAP-MBD2b protein from Ni-NTA chromatography was 3-4 folds higher than that of MBD2b protein (Figure 1(b) and Figure 2(b)), indicating the fusion of SNAP-tag can significantly enhance the expression of the MBD2b protein. When $\mathrm{NaCl}$ concentration was maintained at $150 \mathrm{mmol} / \mathrm{L}$ in the $\mathrm{CXC}$ process, MBD2b protein was stably bonded to the column, while certain amounts of SNAP-MBD2b protein were present in the FT (Figure 2(d) and Figure 1(d)). When we increased $\mathrm{NaCl}$ concentration to $200 \mathrm{mmol} / \mathrm{L}$, a prominent peak appeared companying the decreasing amount of SNAPMBD2b protein, shown in Figure 2(e). For MBD2b, no noticeable peak appeared under $200 \mathrm{mmol} / \mathrm{L} \mathrm{NaCl}$ washing condition (Figure 1(c)). These results suggestes that, compared to SNAP-MBD2b protein, the MBD2b can form more stable complexes with the $\mathrm{CXC}$ resin under the same condition.

To explain the differences between MBD2b and SNAPMBD2b, we predicted their pI using DNAman software, the results were summarized in Table 4 . The MBD2b protein was 9.32, while SNAP-MBD2b protein was 7.79. Fusion of SNAP-tag neutralized part of the positive charge of the MBD2b protein, thus decreasing the binding of SNAP-MBD2b protein to CXC column, reducing the adsorption of SNAP-MBD2b.

\subsection{Labeling of the purified SNAP-MBD2b protein}

Figure 3(a, b) showed that compared to MBD2b, SNAPMBD2b protein was successfully labeled with the fluorescence substrate, indicating the SNAP activity was functional and highly specific. This result showed that the purified protein by this method displayed well-preserved activity. The MBD protein activity didn't show here.

\section{Conclusions}

In conclusion, we demonstrated a simple and efficient twostep method for the purification of MBD2b and SNAPMBD2b proteins by using $\mathrm{AC}$ and $\mathrm{CXC}$ technology. The purification technique has a number of advantages: (a) It can

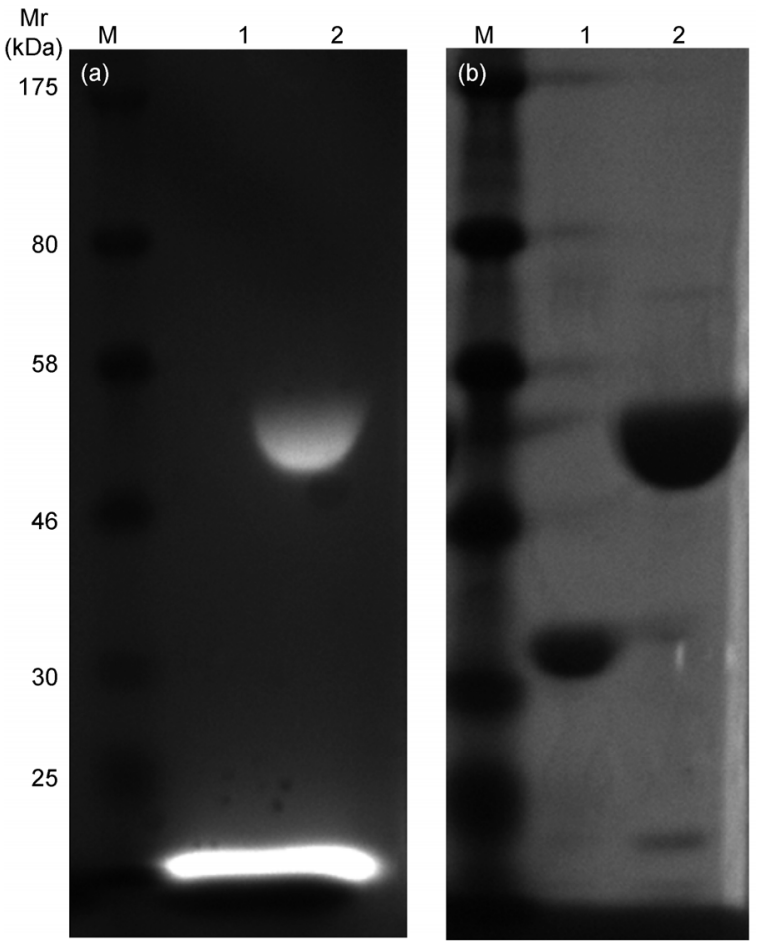

Figure 3 In-gel detection of labeled SNAP-MBD2b protein. Purified SNAP-MBD2b protein was labeled using SNAP-Surface Alexa Flour 488 (NEB). (a) The gel imaged by UV-transilluminator; (b) coomassie staining of proteins. M: pertained protein marker (NEB); 1: labeled MBD2b protein; 2: labeled SNAP-MBD2b protein. The upper fluorescence single band corresponds to the labeled SNAP-MBD2b protein, while the lower corresponds to the unreacted dyes.

recover proteins with more than $93 \%$ purity and wellpreserved activity; (b) It is simple and gentle. Instead of traditional sonication method, the cell was lysed with Bugbuster Protein Extraction Reagent under gentle condition to reduce the protein degradation and preserve protein's binding ability after purification. The eluted product from the AC column can be diluted with the CXC Port A buffer, then loaded directly to the $\mathrm{CXC}$ column without buffer exchange or desalting. The two-step purification strategy and its associated findings may be applied to other affinity tags, such as GST or MBP, fused to MBD protein.

The work was supported by the National Basic Research Program of China (21077129, 20877091, 20890112, 21125523, 20921063) and the National Natural Science Foundation of China (2009CB421605, 2010CB933502).

1 Zilberman D. The human promoter methylome. Nat Genet, 2007, 39: 442-443

2 Clouaire T, Stancheva I. Methyl-CpG binding proteins: specialized transcriptional repressors or structural components of chromatin? Cell Mol Life Sci, 2008, 65: 1509-1522

3 Bollati V, Baccarelli A, Hou L, Bonzini M, Fustinoni S, Cavallo D, Byun HM, Jiang J, Marinelli B, Pesatori AC, Bertazzi PA, Yang AS. Changes in DNA methylation patterns in subjects exposed to low-dose benzene. Cancer Res, 2007, 67: 876-880

4 Yang AS, Estecio MRH, Doshi K, Kondo Y, Tajara EH, Issa JP J. A simple method for estimating global DNA methylation using bisulfite 
PCR of repetitive DNA elements. Nucleic Acids Res, 2004, 32: e38

5 Hendrich B, Bird A. Identification and characterization of a family of mammalian methyl-CpG binding proteins. Mol Cell Biol, 1998, 18: 6538-6547

6 Fodermayr M, Proll J, Zach O, Wechselberger C, Lutz D. In vitro detection of methylated DNA via recombinant protein MBD2b. $\mathrm{Mol}$ Biol Rep, 2009, 36: 1859-1862

7 Zhang Y, Ng H-H, Erdjument-Bromage H, Tempst P, Bird A, Reinberg D. Analysis of the NuRD subunits reveals a histone deacetylase core complex and a connection with DNA methylation. Gene Dev, 1999, 13: 1924-1935

8 Fuks F, Hurd PJ, Wolf D, Nan X, Bird AP, Kouzarides T. The methyl-CpG-binding protein MeCP2 links DNA methylation to histone methylation. J Biol Chem, 2003, 278: 4035-4040

9 Fraga MF, Ballestar E, Montoya G, Taysavang P, Wade PA, Esteller M. The affinity of different MBD proteins for a specific methylated locus depends on their intrinsic binding properties. Nucleic Acids Res, 2003, 31: 1765-1774

10 Rauch T, Pfeifer GP. Methylated-CpG island recovery assay: a new technique for the rapid detection of methylated-CpG islands in cancer. Lab Invest, 2005, 85: 1172-1180

11 Serre D, Lee BH, Ting AH. MBD-isolated genome sequencing provides a high-throughput and comprehensive survey of DNA methylation in the human genome. Nucleic Acids Res, 2010, 38: 391-399

12 Shiraishi M, Sekiguchi A, Oates AJ, Terry MJ, Miyamoto Y, Sekiya T. Methyl-CpG binding domain column chromatography as a tool for the analysis of genomic DNA methylation. Anal Biochem, 2004, 329: $1-10$

13 Hiraoka D, Yoshida W, Abe K, Wakeda H, Hata K, Ilebukuro K. Development of a method to measure DNA methylation levels by using methyl cpg-binding protein and luciferase-fused zinc finger protein. Anal Chem, 2012, 84: 8259-8264

14 Yin H, Zhou Y, Xu Z, Chen L, Zhang D, Ai S. An electrochemical assay for DNA methylation, methyltransferase activity and inhibitor screening based on methyl binding domain protein. Biosens Bioelectron, 2013, 41: 492-497

15 Oliver VF, Wan J, Agarwal S, Zack DJ, Qian J, Merbs SL. A novel methyl-binding domain protein enrichment method for identifying genome-wide tissue-specific DNA methylation from nanogram DNA samples. Epigenet Chromatin, 2013, 6: 17-27

16 Yang Y, Zhang CY. Simultaneous measurement of SUMOylation using SNAP/CLIP-tag-mediated translation at the single-molecule level. Angew Chem Int Ed, 2013, 52: 691-694

17 Sun X, Zhang A, Baker B, Sun L, Howard A, Buswell J, Maurel D, Masharina A, Johnsson K, Noren CJ, Xu MQ, Correa IR. Development of SNAP-tag fluorogenic probes for wash-free fluorescence imaging. Chem Bio Chem, 2011, 12: 2217-2226

18 Hinner MJ, Johnsson K. How to obtain labeled proteins and what to do with them. Curr Opin Biotechnol, 2010, 21: 766-776

19 Mie M, Naoki T, Uchida K, Kobatake E. Development of a split SNAP-tag protein complementation assay for visualization of protein-protein interactions in living cells. Analyst, 2012, 137: 47604765

20 Uhlenheuer DA, Wasserberg D, Haase C, Nguyen HD, Schenkel JH, Huskens J, Ravoo BJ, Jonkheijm P, Brunsveld L. Directed supramolecular surface assembly of snap-tag fusion proteins. Chem Eur J, 2012, 18: 6788-6794

21 Wasserberg D, Uhlenheuer DA, Neirynck P, Cabanas-Danés J, Schenkel JH, Ravoo BJ, An Q, Huskens J, Milroy LG, Brunsveld L, Jonkheijm P. Immobilization of ferrocene-modified SNAP-fusion proteins. Int J Mol Sci, 2013, 14: 4066-4080

22 Suen RB, Lin SC, Hsu WH. Hydroxyapatite-based immobilized metal affinity adsorbents for protein purification. J Chromatogr A, 2004, 1048: 31-39

23 Zhang L, Zhu X, Jiao D, Sun Y, Sun H. Efficient purification of His-tagged protein by superparamagnetic $\mathrm{Fe}_{3} \mathrm{O}_{4} / \mathrm{Au}-\mathrm{ANTA}^{-\mathrm{Co}^{2+}}$ nanoparticles. Mater Sci Eng C, 2013, 33: 1989-1992

24 Wiilfing C, Lombardero J, Pluckthu A. An Escherichia coli protein consisting of a domain homologous to FK506-binding proteins (FKBP) and a new metal binding motif. J Biol Chem, 1994, 269: 2895-2901

25 Bolanos-Garcia VM, Davies OR. Structural analysis and classification of native proteins from $E$. coli commonly co-purified by immobilised metal affinity chromatography. Biochim Biophys Acta, 2006, 1760: 1304-1313

26 Pessela BCC, Munilla R, Betancor L, Fuentes M, Carrascosa AV, Vian A, Fernandez-Lafuente R, Guisan JM. Ion exchange using poorly activated supports, an easy way for purification of large proteins. J Chromatogr A, 2004, 1034: 155-159

27 Li K, Liu S, Xing R, Yu H, Qin Y, Li R, Li P. High-resolution separation of homogeneous chitooligomers series from 2-mers to 7-mers by ion-exchange chromatography. J Sep Sci, 2013, 36: 1275-1282 